Acta Sci. Pol. Technol. Aliment. 18(3) 2019, 249-256

pISSN 1644-0730

eISSN 1898-9594

http://dx.doi.org/10.17306/J.AFS.2019.0673

ORIGINAL PAPER

Received: 1.06.2019

Accepted: 5.07.2019

\title{
OPTIMISATION OF ULTRASONIC-ASSISTED EXTRACTION OF BIOACTIVE COMPOUNDS FROM CHOKEBERRY POMACE USING RESPONSE SURFACE METHODOLOGY
}

\author{
Sylwia Sady ${ }^{1 \bowtie}$, Leszek Matuszak², Alfred Błaszczyk ${ }^{1}$ \\ 1Department of Natural Science and Quality Assurance, Poznań University of Economics and Business \\ Niepodległości 10, 61-875 Poznań, Poland \\ 2Department of Product Marketing, Poznań University of Economics and Business \\ Niepodległości 10, 61-875 Poznań, Poland
}

\begin{abstract}
Background. Chokeberry pomace is a valuable by-product of fruit processing because of its high levels of phenolic compounds and anthocyanins. The study was aimed to optimise chokeberry pomace extraction of total phenolic content, total anthocyanin content and antioxidant activity using response surface methodology. Material and methods. Response surface methodology was used to evaluate the effect of the concentration of ethanol (in the range of 60-96\%) and sonication time (from 10 to $30 \mathrm{~min}$ ) as independent variables on total phenolic content, antioxidant capacity and total anthocyanin content as the response functions.

Results. The results showed that ethanol concentration, but not sonication time, had a significant influence on total phenolic content, antioxidant activity and total anthocyanin content. The optimal extraction conditions for total phenolic content (188.5 mg GAE/g DM) and antioxidant capacity (49.2 mM Tr/100 g DM) were $60 \%$ ethanol and $20 \mathrm{~min}$ sonication time. The optimal conditions in the case of total anthocyanin content (89.3 mg C3GE/g) were an $65 \%$ ethanol concentration and 13 min sonication time.

Conclusion. The development of optimal extraction parameters should allow food producers to use efficient, cost-effective and environmentally friendly technology to isolate biologically active molecules from chokeberry pomace, while the selected extract could be a component of health-promoting bioactive products.
\end{abstract}

Keywords: response surface methodology, chokeberry pomace, ultrasonic-assisted extraction, total phenolic content, antioxidant activity, total anthocyanin content

\section{INTRODUCTION}

In recent years, there has been a strong trend towards using plant extracts as functional ingredients in food, beverage, pharmaceutical, nutraceutical and cosmetic industries (Barbulova et al., 2015; Varzakas et al., 2016). Modifications to traditional recipes by adding natural plant extracts have become a way to improve the quality of food products and develop their functionality (Skąpska et al., 2017). In addition to satisfying human nutritional needs, products enriched with natural extracts have a significant impact on preventing civilisation diseases (Abdel-Salam, 2010; Sun et al., 2016). For that reason, it is important to conduct new research on bioactivity and chemical characteristics of unknown or little-known plant materials. As a result of such studies, innovative extraction methods using ultrasounds have been developed. They allow different 
valuable polyphenolic compounds of great scientific and commercial importance to be discovered. Ultrasound can be treated as a highly efficient technique to be implemented in the food industry because of high reproducibility, short duration, reduction of the processing costs, simplifying manipulation and work-up, higher purity of the final product and low energy consumption (Giacometti et al., 2018).

Aronia (Aronia melanocarpa E.), also called the chokeberry, is one of the most popular berries. It is well-known for having high polyphenol content, including anthocyanins, hydroxycinnamic acids and procyanidins (Kulling and Rawel, 2008; Taheri et al., 2013). These compounds significantly influence the health-promoting properties of aronia such as antiproliferative and anti-carcinogenic effects, as well as the sensory properties of fresh and processed fruits a characteristic tart taste and violet colour (Kulling and Rawel, 2008; Ochmian et al., 2012; Thi and Hwang, 2014). A study by Peschel et al. (2006) shows that byproducts from the food industry, especially pomaces which consist of seeds, pulp residues and peels, have strong antioxidant properties. Chokeberry pomace as a by-product of chokeberry fruit processing is a source of bioactive compounds, especially anthocyanins, that protect cells from the harmful effects of free radicals (Lipińska et al., 2017).

In recent years, more and more studies on the extraction of bioactive compounds from various plants have focused on process optimisation (Cheng and Hong, 2018; Ilghami et al., 2015; Tomšik et al., 2016). Searching for optimal extraction conditions through a one-dimensional method, where only one of the factors is modified, while all other are constant values, is very time-consuming and expensive. Moreover, a significant drawback of such an approach is the inability to detect potential interactions that may occur between individual conditions. In this situation, an alternative to a standard one-dimensional approach is to use response surface methodology (RSM), which is particularly useful when the phenomenon being studied is affected by at least two factors. The main concept of this method is to determine the plan of the experiment, and then to determine the relations between the variables analysed and to define the optimal parameters of the process that are in compliance with previously set conditions with the use of mathematical and statistical analyses (Granato and de Araujo Calado, 2014).

The aim of the study is to optimise the process of extraction of polyphenolic compounds and anthocyanins and to assess antiradical activity of chokeberry extracts based on applied response surface methodology.

\section{MATERIAL AND METHODS}

\section{Plant material}

Chokeberry fruits (cultivar: 'Nero') were harvested at the beginning of September 2017 at the plantation in Marwice (Poland). The washed fruits were then subjected to a pressing process to obtain the chokeberry pomace. This pomace was subsequently frozen and subjected to a freeze-drying process, which consisted of two stages: freezing (at $-45^{\circ} \mathrm{C}$ ) and drying (from $12^{\circ} \mathrm{C}$ to $48^{\circ} \mathrm{C}$ ). The entire drying process was carried out for $16 \mathrm{~h}$ and $15 \mathrm{~min}$. The freeze-dried chokeberry pomace was grounded to powder in Minichiller 300 (HUBER, Germany) for 20 seconds. The fraction obtained (with particle size of $8.89 \mu \mathrm{m}$ ) was then subjected to extraction.

\section{Reagents and equipments}

2,2-diphenyl-1-picrylhydrazyl (DPPH), Folin-Ciocalteu reagent, 3,4,5-trihydroxybenzoic acid (Gallic acid) and 6-hydroxy-2,5,7,8-tetramethylchromane-2-carboxylic acid (Trolox) were purchased from Sigma-Aldrich (Munich, Germany). Ethanol, potassium chloride and sodium carbonate were purchased from Avantor Performance Materials (Gliwice, Poland). Sodium acetate was purchased from Chempur (Piekary Śląskie, Poland). All chemicals and reagents were of analytical grade.

The freeze-drying process was carried out using a TG15 lyophilizer by an external company Naturim (Włocławek, Poland). The entire extraction process used a Vibra-Cell ultrasonic processor (130 Watt, $20 \mathrm{kHz}$ ). Spectrophotometric assays were performed using a V-770 double-beam Jasco spectrophotometer.

\section{Preparation of the extracts}

The ultrasonic-assisted extraction process was carried out in three stages. In the first stage, $5 \mathrm{~g}$ of the lyophilizate was added to $50 \mathrm{~mL}$ of a solvent mixture of ethanol and water. The range of ethanol concentration 
Sady, S., Matuszak, L., Błaszczyk, A. (2019). Optimisation of ultrasonic-assisted extraction of bioactive compounds from chokeberry pomace using response surface methodology. Acta Sci. Pol. Technol. Aliment., 18(3), 249-256. http://dx.doi.org/10.17306/ J.AFS.2019.0673

Table 1. Independent variables and their coded and actual values used for optimisation

\begin{tabular}{lccccccc}
\hline \multirow{2}{*}{$\begin{array}{l}\text { Independent } \\
\text { variables }\end{array}$} & Unit & Symbol & \multicolumn{6}{c}{ Coded levels } \\
\cline { 4 - 8 } & & $-\alpha$ & -1 & 0 & 1 & $+\alpha$ \\
\hline $\begin{array}{l}\text { Ethanol } \\
\text { concentration }\end{array}$ & $\%$ & $X_{1}$ & 60 & 65 & 78 & 90 & 96 \\
$\begin{array}{l}\text { Sonication } \\
\text { time }\end{array}$ & min & $X_{2}$ & 10 & 13 & 20 & 27 & 30 \\
& & & & & & & \\
\hline
\end{tabular}

in water and the sonication time adopted in the experiment are shown in Table 1 and Table 2. The constant parameters of the extraction process in all experiments were: temperature $\left(25 \pm 1^{\circ} \mathrm{C}\right)$, amplitude $(50 \mu \mathrm{m})$ and the ratio of the raw material mass to the amount of solvent (1:10). During the extraction, the amount of ultrasonic energy was injected into the sample was monitored and the intensity of the ultrasonic wave was calculated, which allowed it to be established whether the phenomenon of cavitation occurred. In next stages, the sample was again poured with fresh solvent mixture. After each step, the extracts were filtered through a sintered glass filtration set. The resulting filtrates were combined and concentrated using a rotary evaporator at $30 \pm 1{ }^{\circ} \mathrm{C}$, protecting the sample from light. The concentrated extracts were then transferred to $25 \mathrm{~mL}$ volumetric flasks and topped up with ethanol at the appropriate concentration. The prepared extracts were stored at $-20^{\circ} \mathrm{C}$ until analysis. The $\mathrm{pH}$ values of ethanolic chokeberry extracts were measured using a $\mathrm{HI}$ $5221 \mathrm{pH}$ meter (HANNA Instruments, Poland). The $\mathrm{pH}$ values of all the extracts investigated ranged from 4.4 to 4.9 .

\section{Total phenolic content}

The determination of total phenolic content (TPC) was carried out using the colorimetric method described by Singleton and Rossi (1965). Into the volumetric flasks $(10 \mathrm{~mL})$ the following were successively added: $5 \mathrm{~mL}$ of distilled water, $0.5 \mathrm{~mL}$ of Folin-Ciocalteu reagent and $0.1 \mathrm{~mL}$ of the sample. After $3 \mathrm{~min}$ of incubation at room temperature, $1.5 \mathrm{~mL}$ of a $20 \%$ sodium carbonate solution was added to the flasks, which were then filled up with distilled water to the mark. After $2 \mathrm{~h}$, the absorbance was measured at $725 \mathrm{~nm}$. The reference used was made analogously, except for adding water instead of the sample. Total phenolic content in the

Table 2. Central composite design with experimental and predicted values for TPC, DPPH and TAC

\begin{tabular}{|c|c|c|c|c|c|c|c|c|c|c|c|}
\hline \multirow{3}{*}{$\begin{array}{c}\begin{array}{c}\text { Standard } \\
\text { order }^{*}\end{array} \\
1\end{array}$} & \multirow{3}{*}{$\begin{array}{l}\text { Run } \\
\text { order }^{* *}\end{array}$} & \multicolumn{4}{|c|}{ Coded and uncoded variables } & \multicolumn{2}{|c|}{$\begin{array}{c}\text { Response }\left(Y_{1}\right) \\
\text { TPC } \\
\text { mg GAE/g DM }\end{array}$} & \multicolumn{2}{|c|}{$\begin{array}{c}\text { Response }\left(Y_{2}\right) \\
\text { DPPH } \\
\mathrm{mM} \mathrm{Tr} / 100 \mathrm{~g} \mathrm{DM}\end{array}$} & \multicolumn{2}{|c|}{$\begin{array}{c}\text { Response }\left(Y_{3}\right) \\
\text { TAC } \\
\text { mg C3GE/g DM }\end{array}$} \\
\hline & & \multicolumn{2}{|c|}{$\begin{array}{c}X_{1}(\text { ethanol con- } \\
\text { centration, \%) }\end{array}$} & \multicolumn{2}{|c|}{$\begin{array}{l}X_{2} \text { (sonication } \\
\text { time, } \min )\end{array}$} & \multirow{2}{*}{$\begin{array}{c}\begin{array}{c}\text { experi- } \\
\text { mental } \\
\text { value }\end{array} \\
188.5\end{array}$} & \multirow{2}{*}{$\begin{array}{c}\text { predicted } \\
\text { value }\end{array}$} & \multirow{2}{*}{$\begin{array}{c}\begin{array}{c}\text { experi- } \\
\text { mental } \\
\text { value }\end{array} \\
49.2\end{array}$} & \multirow{2}{*}{$\begin{array}{c}\text { predicted } \\
\text { value }\end{array}$} & \multirow{2}{*}{$\begin{array}{c}\begin{array}{c}\text { experi- } \\
\text { mental } \\
\text { value }\end{array} \\
88.3\end{array}$} & \multirow{2}{*}{$\begin{array}{c}\begin{array}{c}\text { predicted } \\
\text { value }\end{array} \\
86.4\end{array}$} \\
\hline & & -1.41 & $(60)$ & 0 & $(20)$ & & & & & & \\
\hline 2 & $10(\mathrm{C})$ & 0 & $(78)$ & 0 & $(20)$ & 137.8 & 139.3 & 37.9 & 38.6 & 86.7 & 86.7 \\
\hline 3 & $9(\mathrm{C})$ & 0 & $(78)$ & 0 & $(20)$ & 140.4 & 139.3 & 39.9 & 38.6 & 86.3 & 86.7 \\
\hline 4 & 2 & -1 & $(65)$ & 1 & $(27)$ & 157.7 & 163.1 & 44.4 & 44.9 & 85.1 & 85.7 \\
\hline 5 & 7 & 0 & $(78)$ & -1.41 & $(10)$ & 144.5 & 148.0 & 39.9 & 39.6 & 87.9 & 88.3 \\
\hline 6 & 1 & -1 & $(65)$ & -1 & (13) & 181.7 & 182.2 & 46.1 & 47.1 & 89.3 & 90.7 \\
\hline 7 & 6 & 1.41 & (96) & 0 & (20) & 95.9 & 99.6 & 26.3 & 27.2 & 68.7 & 72.1 \\
\hline 8 & 4 & 1 & (90) & 1 & (27) & 114.8 & 114.6 & 33.1 & 32.1 & 82.7 & 79.5 \\
\hline 9 & 8 & 0 & (78) & 1.41 & (30) & 140.0 & 136.3 & 38.6 & 38.9 & 84.4 & 85.9 \\
\hline 10 & 3 & 1 & (90) & -1 & (13) & 118.2 & 112.7 & 31.5 & 31.0 & 80.6 & 78.1 \\
\hline
\end{tabular}

*Non-randomised order.

${ }^{* *}$ Randomised order. 
extracts was determined based on a standard curve as the equivalent of gallic acid per $g$ of dry matter (DM) of extract (mg GAE/g).

\section{Antioxidant capacity}

The assessment of DPPH radical scavenging activity of chokeberry pomace extracts was conducted based on the method described by Sanchez-Moreno et al. (1998) with a modification using 2,2-diphenyl-1-picrylhydrazyl (DPPH) dissolved in $96 \%$ ethanol at a concentration of $0.0025 \mathrm{~g} / 100 \mathrm{~mL}$. The absorbance was measured for $10 \mathrm{~min}$ at $515 \mathrm{~nm}$. The reduction of DPPH radical after $10 \mathrm{~min}$ of incubation of the sample was calculated. In order to standardise the results, a standard curve was prepared for the reaction mixture of $2.4 \mathrm{~mL}$ DPPH radical solution and $0.1 \mathrm{~mL}$ Trolox solution after $10 \mathrm{~min}$ incubation. The concentration range of Trolox from 0 to $0.025 \mu \mathrm{mol} / \mathrm{mL}$ of the reaction mixture was used. The results were expressed in $\mathrm{mM}$ Tr/100 g DM.

\section{Total anthocyanin content}

The analysis of total anthocyanin content (TAC) was based on the measurement of the absorbance at two various wavelengths: $510 \mathrm{~nm}$ and $700 \mathrm{~nm}$ (Çam et al., 2009). In order to prepare the sample for assay, two cuvettes were filled in as following: $2.7 \mathrm{~mL}$ of buffer $\mathrm{pH}=1.0$ and $0.3 \mathrm{~mL}$ of sample, $2.7 \mathrm{~mL}$ of buffer $\mathrm{pH}=4.5$ and $0.3 \mathrm{~mL}$ of sample. The difference in absorbance at $\mathrm{pH}=1.0$ and $\mathrm{pH}=4.5$ was calculated. TAC was expressed as mg cyanidin 3-glucoside (C3GE) equivalent per $g$ of DM of the extract. Spectrophotometric assays were performed in triplicate for each batch.

\section{Experimental design and statistical analysis RSM}

Response surface methodology was used to evaluate the effect of the concentration of ethanol and sonication time as independent variables on total phenolic content, antioxidant capacity and total anthocyanin content as the response functions. The experimental data were evaluated using a central composite design (CCD). The ranges and central point values of two process variables are shown in Table 1 . The ranges of ethanol concentration (60-96\%) and sonication time (10-30 $\mathrm{min}$ ) were selected based on literature findings (Jeszka-Skowron et al., 2014; Liu et al., 2018) and the authors' previous experiments.
The relation between the coded values and actual values used for statistical analysis was measured. After conducting the experiment, the data were fitted with a second-degree polynomial equation as follows:

$$
Y=\beta_{0}+\sum_{i=1}^{2} \beta_{i} X_{i}+\sum_{i=1}^{2} \beta_{i i} X_{i}^{2}+\sum_{i=1}^{2} \beta_{i j} X_{i} X_{j}+\varepsilon
$$

where:

$Y$ - the predicted responses(TPC,DPPH and TAC),

$\beta$-the model constant,

$\beta_{i}, \beta_{\mathrm{ii}}, \beta_{\mathrm{ij}}-$ model coefficients (linear, squared and interactive effects),

$\varepsilon$-the error.

The design of the experiments, analysis of the results and prediction of the responses were carried out using a commercial statistical package, Statistica 13.1 (StatSoft). Statistical significance in the regression equations was examined by analysis of variance (ANOVA). The adequacy of the models was determined using model analysis, a lack-of-fit test, determination coefficient $\left(R^{2}\right)$ and adjusted determination coefficient $\left(R_{a}^{2}\right)$. The significant differences between the mean values were assessed using Tukey's test $(p \leq 0.05)$. In the last stage of the study, the validation of the model was performed.

\section{RESULTS AND DISCUSSION}

In the first stage of the study, the assessment of the impact of selected factors $\left(X_{1}\right.$ and $\left.X_{2}\right)$ on total phenolic content, antioxidant capacity and total anthocyanin content of chokeberry ("Nero" cultivar) ethanolic extracts was carried out. Ethanol and aqueous-ethanolic systems are frequently used as a solvent for the extraction of phenolic compounds, also from chokeberries, because of their moderate polarity and many other advantages, such as low toxicity, high extraction yield and minimal deleterious effects on people and environment (Simić et al., 2016). The results of a study by Thi and Hwang (2014) showed that significantly higher TPC and antioxidant activity were found in ethanolic extracts compared to aqueous extracts.

The scheme of the experiment and results obtained as the averages of three replicates are presented in Table 2. Among the extracts analysed, the highest total phenolic content and antioxidant capacity were determined in the extract samples at the level of $60 \%$ ethanol 
Sady, S., Matuszak, L., Błaszczyk, A. (2019). Optimisation of ultrasonic-assisted extraction of bioactive compounds from chokeberry pomace using response surface methodology. Acta Sci. Pol. Technol. Aliment., 18(3), 249-256. http://dx.doi.org/10.17306/ J.AFS.2019.0673

Table 3. The fitted quadratic model in terms of coded variables for TPC, DPPH and TAC responses

\begin{tabular}{ccccc}
\hline \multirow{2}{*}{ Responses } & \multicolumn{1}{c}{ Second degree polynomial equation } & $\begin{array}{c}\text { Regression } \\
(p \text {-value })\end{array}$ & $R_{2}$ & $R_{a}^{2}$ \\
\hline$Y_{1}$ & $488.75-481.89 X_{1}+81.35 X_{1}^{2}-6.41 X_{2}+0.029 X_{2}^{2}+6.00 X_{1} X_{2}$ & 0.0001 & 0.984 & 0.964 \\
$Y_{2}$ & $84.29-32.30 X_{1}-28.43 X_{1}^{2}-1.009 X_{2}+0.006 X_{2}^{2}+0.929 X_{1} X_{2}$ & 0.0001 & 0.988 & 0.973 \\
$Y_{3}$ & $9.804 .21+282.718 X_{1}-229.651 X_{1}^{2}-1.66 X_{2}+0.004 X_{2}^{2}+1.782 X_{1} X_{2}$ & 0.0001 & 0.888 & 0.747 \\
\hline
\end{tabular}

$Y_{1}-\mathrm{TPC}, Y_{2}-\mathrm{DPPH}, Y_{3}-\mathrm{TAC}$.

concentration and at 20 min sonication time, while the highest total anthocyanin content was determined in the extract samples at $65 \%$ ethanol concentration and at 13 min sonication time. The lowest values of TPC, antioxidant capacity and TAC were determined at a $96 \%$ ethanol concentration and after 20 min of sonication. Total phenolic content in the extract samples ranged from 95.9 to $188.5 \mathrm{mg} \mathrm{GAE} / \mathrm{g} \mathrm{DM}$, antioxidant capacity was measured in the range of $26.3-49.2 \mathrm{mM}$ $\mathrm{Tr} / 100 \mathrm{~g}$ DM, while total anthocyanin content ranged from 68.7 to $89.3 \mathrm{mg} \mathrm{C} 3 \mathrm{GE} / \mathrm{g} \mathrm{DM}$ (Table 2). The study by Cvetković et al. (2018) proved that extraction conditions such as type and concentration of solvents, reaction time and temperature had a significant impact on levels of total phenolic content and antioxidant activity in chokeberry leaves. Simić et al. (2016) used RSM to determine the optimum parameters for achieving a maximal yield of TPC from whole chokeberries and stated that the optimal extraction time and ethanol concentration were $15 \mathrm{~min}$ and $53.8 \%$, respectively. In a different study concerning commercial frozen chokeberries, the optimal extraction parameters for extractive substances yield were: $15 \mathrm{~min}$ extraction time and $62.5 \%$ ethanol concentration (Simić et al., 2018). Xu et al. (2017) studied the optimisation of ultrasound-assisted aqueous two-phase system extraction of phenolic compounds from chokeberry pomace. The authors identified the optimal parameters by RSM at the levels of $69 \%$ ethanol concentration (from the range of $60-80 \%$ ) and $50 \mathrm{~min}$ sonication time (from the range of 40-60 $\mathrm{min}$ ), which allowed $68.15 \mathrm{mg} \mathrm{GAE} / \mathrm{g}$ of TPC to be extracted. In the study by Gao et al. (2016), the optimal ethanol concentration for ultrasound extraction of phenolic compounds from chokeberry pulp was $56 \%$. According to Chen et al. (2018), the optimal ultrasound-assisted extraction conditions for determining TAC in chokeberries were: ethanol concentration $62 \%$ and ultrasonic time $44 \mathrm{~min}$. Under these conditions (with ultrasonic power $198 \mathrm{~W}$ and liquid-solid ratio $19 \mathrm{~mL} / \mathrm{g}$ ), The authors obtained $4.319 \mathrm{mg} \mathrm{C} 3 \mathrm{GE} / \mathrm{g}$ of anthocyanins.

In the second stage of the study, regression models in the form of second degree polynomial equations were determined for TPC $\left(Y_{1}\right)$, DPPH $\left(Y_{2}\right)$ and TAC $\left(Y_{3}\right)$ values (Table 3$)$. The response models described the variability of the analysed phenomenon well: they explained from nearly $89 \%$ to almost $99 \%$ variability. They were characterised by a good fit, as indicated by the value of the $R^{2}$ determination coefficient. For TPC and DPPH, $R^{2}$ values were close to 1 and equalled 0.984 and 0.988 , respectively. The statistically insignificant value of lack-of-fit for TPC and DPPH indicates that regression models correspond well with experimental data. In the case of TAC, the value of lack-of-fit is statistically significant, but also that model is characterised by high values of $R^{2}(0.888)$ and $R^{2}{ }_{a}$ (0.747). Joglekar and May (1987) stated that $R^{2}$ should be at least 0.800 for a good fit of a response model. Since the $R^{2}$ values for the response variables were higher than 0.800 , the regression models were suitable to explain their behaviour.

The mathematical models in the form of second degree polynomial equations used to describe the results obtained were statistically significant at the level of $p<0.0001$. For DPPH none of the residuals exceeded $4 \%$ of experimental values, while the mean absolute percentage error (MAPE) was $1.8 \%$. For TPC, MAPE was $2.2 \%$, with the biggest difference between the model and the experimental data being related to high (over 90\%) concentrations of ethanol. In the case of TAC, MAPE was $1.98 \%$. Accordingly, a good fit can be evaluated for $Y_{1}, Y_{2}$ and for which there is a high compatibility of the empirical model with the actual data. Statistical analysis showed that among 


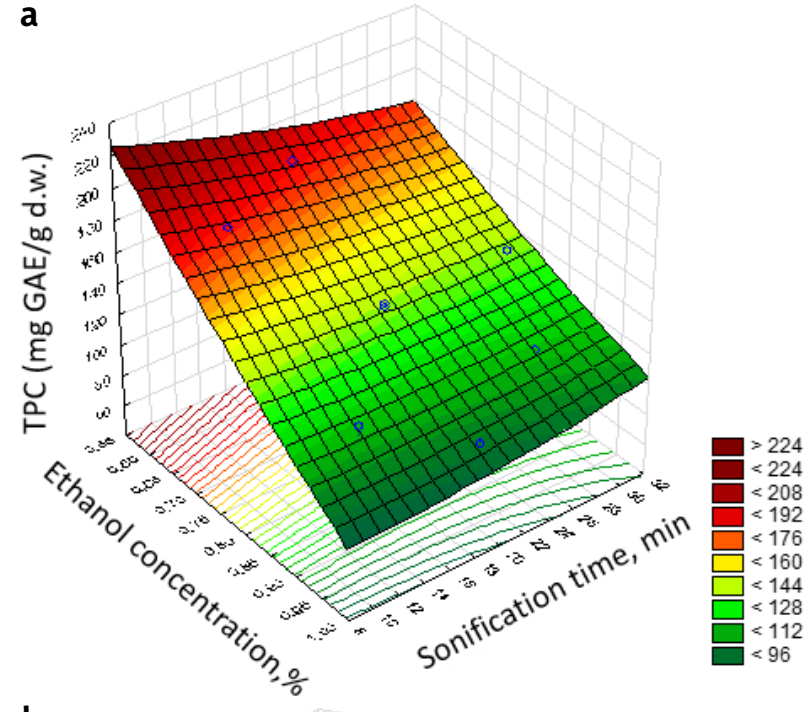

b

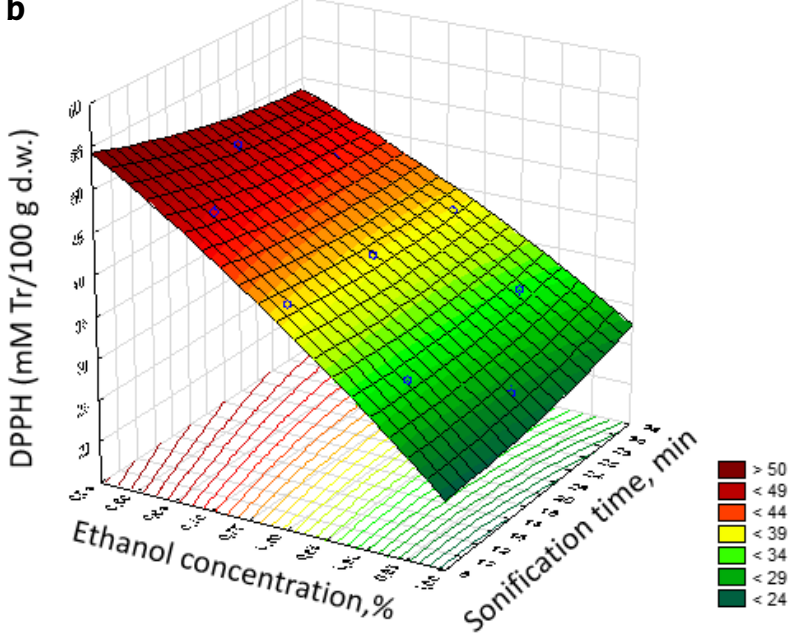

C

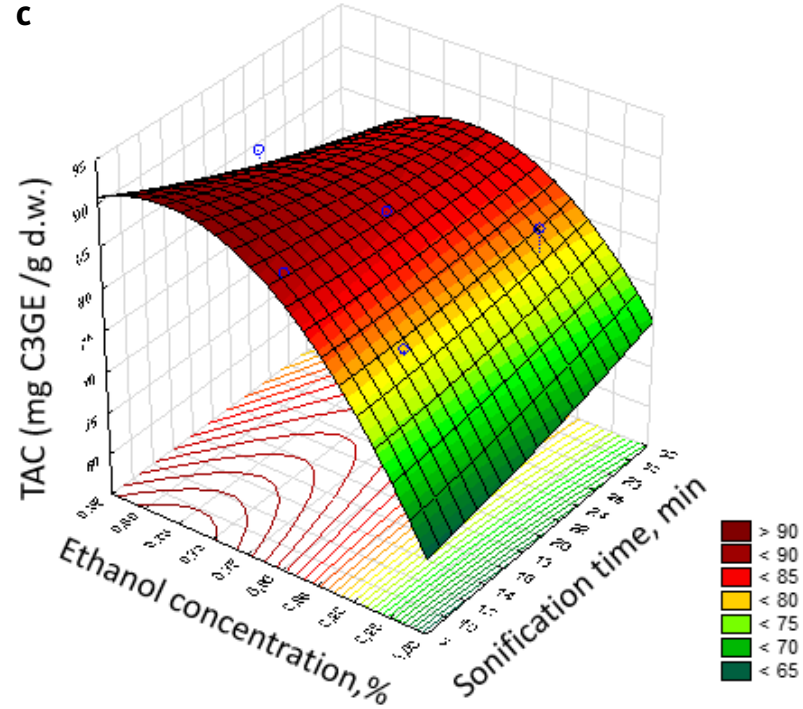

the variables assessed, ethanol concentration $\left(X_{1}, p=\right.$ $0.014, p=0.029$ and $p=0.014$ ) had a significant influence on the amounts of total phenolic content, antioxidant capacity and total anthocyanin content obtained, while the sonication time, based on the analysis of variance, did not significantly differentiate the level of these responses. At the same time, the lack-of-fit was also significant, which means that the results in that case are not ambiguous.

The generated response surface plots (Fig. 1) show the interactive effect of ethanol concentration and sonication time on total phenolic content, DPPH radical scavenging activity and total anthocyanins content. The shape of the surface indicates that in each of the cases analysed, the ethanol concentration is the most important factor. The lower ethanol concentration was used, the higher extraction efficiency was achieved. When reflecting especially to the first two charts, it can be noticed that the sonication time does not affect the extraction results or affects them in a non-significant manner.

In the last stage of the study, the validation of the model was performed for four ethanol concentrations in 20 min sonication time: $62 \%, 75 \%, 55 \%$ and $50 \%$ (Table 4). Validation of the model at two levels $(62 \%$ and $75 \%)$ showed that the model corresponds well with the experimental data, since it was validated with an error of less than $10 \%$. For TAC, deviations were around $1 \%$, while for TPC and DPPH, they were in the range from $1-6 \%$. Such results can be considered as satisfactory. Due to the fact that the optimal parameters of the model were close to the lower limit of the tested ethanol concentrations, it was verified whether the model also works for concentrations below $60 \%$. For $55 \%$ and $50 \%$ ethanol concentrations, the predicted data deviated from the experimental data by over $45 \%$ for TPC, $35-40 \%$ for DPPH and $1-7 \%$ for TAC. At the same time, the extraction results for ethanol concentrations below the range analysed (60-96\%) were clearly lower (by $15 \%$ for TPC, by $11 \%$ for DPPH and by $2 \%$ for TAC) than

Fig. 1. Response surface plot showing the interactive effect of ethanol concentration and sonication time on: $\mathbf{a}$ - total phenolic content - TPC, $\mathbf{b}-$ DPPH radical scavenging activity, $\mathbf{c}$ - total anthocyanin content - TAC 
Sady, S., Matuszak, L., Błaszczyk, A. (2019). Optimisation of ultrasonic-assisted extraction of bioactive compounds from chokeberry pomace using response surface methodology. Acta Sci. Pol. Technol. Aliment., 18(3), 249-256. http://dx.doi.org/10.17306/ J.AFS.2019.0673

Table 4. Validation of optimized model

\begin{tabular}{cccccccc}
\hline \multicolumn{2}{c}{ Uncoded variables } & \multicolumn{2}{c}{$\begin{array}{c}\text { Response }\left(Y_{1}\right) \\
\text { TPC, mg GAE/g DM }\end{array}$} & $\begin{array}{c}\text { Response }\left(Y_{2}\right) \\
\text { DPPH, mM Tr/100 g DM }\end{array}$ & \multicolumn{2}{c}{$\begin{array}{c}\text { Response }\left(Y_{3}\right) \\
\text { TAC, mg C3GE/g DM }\end{array}$} \\
\hline $\begin{array}{c}X_{1} \text { (ethanol } \\
\text { concentra- } \\
\text { tion, \%) }\end{array}$ & $\begin{array}{c}X_{2} \text { (sonica- } \\
\text { tion time, } \\
\text { min) }\end{array}$ & $\begin{array}{c}\text { experimental } \\
\text { value }\end{array}$ & $\begin{array}{c}\text { predicted } \\
\text { value }\end{array}$ & $\begin{array}{c}\text { experimental } \\
\text { value }\end{array}$ & $\begin{array}{c}\text { predicted } \\
\text { value }\end{array}$ & $\begin{array}{c}\text { experimental } \\
\text { value }\end{array}$ & $\begin{array}{c}\text { predicted } \\
\text { value }\end{array}$ \\
\hline 62 & 20 & 183.9 & 179.0 & 47.6 & 47.1 & 88.6 & 87.3 \\
75 & 20 & 155.3 & 146.5 & 42.9 & 40.2 & 87.1 & 87.8 \\
55 & 20 & 134.4 & 197.7 & 37.2 & 50.4 & 84.8 & 83.8 \\
50 & 20 & 136.0 & 211.5 & 37.5 & 52.5 & 85.5 & 80.0 \\
\hline
\end{tabular}

the results obtained for the optimal level of ethanol concentration (60\%).

For the first time for chokeberry pomace, the response surface experiment of two factors (ethanol concentration and ultrasonic time) was carried out with TPC, TAC and DPPH as the response values. Gao et al. (2016) and Chen et al. (2018) used only one response value each - polyphenol and anthocyanin yield, respectively, whereas in RSM Xu et al. (2017) applied total polyphenolic and flavonoids yields as the response values. What is more, in our experiment we used lyophilized pomace instead of whole frozen berries (Gao et al., 2016; Chen et al., 2018) or air-dried pomace (Xu et al., 2017) and it was performed at room temperature, and with a shorter extraction time, while the validation of the model obtained was performed with an error of less than $10 \%$.

The study proves that sonication is an effective method for the extraction of polyphenolic compounds from chokeberry pomace using the optimal ethanol concentration and in a reasonable extraction time. RSM was successfully applied in order to optimise the bioactive compounds extraction process of Aronia melanocarpa pomace. Optimal sonication conditions were established after performing the minimum number of experiments of 10 .

\section{REFERENCES}

Abdel-Salam, A. M. (2010). Functional foods: hopefulness to good health. Am. J. Food Technol., 5(2), 86-99. https://doi.org/10.3923/ajft.2010.86.99

Barbulova, A., Colucci, G., Apone, F. (2015). New trends in cosmetics: by-products of plant origin and their potential use as cosmetic active ingredients. Cosmetics, 2(2), 82-92. https://doi.org/10.3390/cosmetics2020082

Çam, M., Hisil, Y., Durmaz, G. (2009). Classification of eight pomegranate juices based on antioxidant capacity measured by four methods. Food Chem., 112(3), 721726. https://doi.org/10.1016/j.foodchem.2008.06.009

Chen, S., Meng, X., Wang, Y., Sun, X. (2018). Antioxidant activity and optimisation of ultrasonic-assisted extraction by response surface methodology of Aronia melanocarpa anthocyanins. Matrix Sci. Pharm., 2, 6-9. https://doi.org/10.26480/msp.01.2018.06.09

Cheng, C. L., Hong, G. B. (2018). Optimization of extraction process for bioactive compounds from Litsea cube$b a$ fruits. Korean J. Chem. Eng., 35(1), 187-194. https:// doi.org/10.1007/s11814-017-0251-6

Cvetković, D., Stanojević, L., Zvezdanović, J., Savić, S., Ilić, D., Karabegović, I. T. (2018). Aronia leaves at the end of harvest season - Promising source of phenolic compounds, macro- and microelements. Sci. Hortic., 239, 17-25. https://doi.org/10.1016/j.scienta.2018.05.015

Gao, N., Li, B., Chou, S., Yang, P., Li, E., Zhang, Y. (2016). Optimization for ultrasound extraction of polyphenol from Aronia melanocarpa (chokeberry) with antioxidant activity. J. Food Eng. Technol., 5, 20-28.

Giacometti, J., Žauhar, G., Žuvić, M. (2018). Optimization of ultrasonic-assisted extraction of major phenolic compounds from olive leaves (Olea europaea L.) using response surface methodology. Foods, 7(9), 149. https:// doi.org/10.3390/foods7090149

Granato, D., de Araujo Calado, V. M. (2014). The use and importance of design of experiments (DOE) in process modelling in food science and technology. In D. Granato, G. Ares (Eds.), Mathematical and statistical methods in food science and technology (pp. 1-18). Hoboken, NJ: Wiley-Blackwell. 
Sady, S., Matuszak, L., Błaszczyk, A. (2019). Optimisation of ultrasonic-assisted extraction of bioactive compounds from chokeberry pomace using response surface methodology. Acta Sci. Pol. Technol. Aliment., 18(3), 249-256. http://dx.doi.org/10.17306/ J.AFS.2019.0673

Ilghami, A., Ghanbarzadeh, S., Hamishehkar, H. (2015). Optimization of the ultrasonic-assisted extraction of phenolic compounds, ferric reducing activity and antioxidant activity of the Beta vulgaris using response surface methodology. Pharm. Sci., 21, 46-50. https://doi. org/10.15171/PS.2015.16

Jeszka-Skowron, M., Flaczyk, E., Kobus-Cisowska, J., Kośmider, A., Górecka, D. (2014). Optymalizacja procesu ekstrakcji związków fenolowych o aktywności przeciwrodnikowej z liści morwy białej za pomocą metody płaszczyzny odpowiedzi (RSM) [Optimizing process of extracting phenolic compounds having antiradical activity from white mulberry leaves by means of response surface methodology (RSM)]. Żywn. Nauk. Technol. Jakość, 92(1), 148-159 [in Polish].

Joglekar, A. M., May, A. T. (1987). Product excellence through design of experiments. Cereal Food. World, 32, $857-868$.

Kulling, S. E., Rawel, H. M. (2008). Chokeberry (Aronia melanocarpa) - A review on the characteristic components and potential health effects. Planta Med., 74, 1625-1634. https://doi.org/10.1055/s-0028-1088306

Lipińska, P., Atanasov, A. G., Palka, M., Jóźwik, A. (2017). Chokeberry pomace as a determinant of antioxidant parameters assayed in blood and liver tissue of Polish Merino and Wrzosówka lambs. Molecules, 22, e1461. https://doi.org/10.3390/molecules22111461

Liu, Y., She, X. R., Huang, J. B., Liu, M. C., Zhan, M. E. (2018). Ultrasonic-extraction of phenolic compounds from Phyllanthus urinaria: optimization model and antioxidant activity. Ciênc. Tecnol. Aliment., in press. https://doi.org/10.1590/1678-457x.21617

Ochmian, I. D., Grajkowski, J., Smolik, M. (2012). Comparison of some morphological features, quality and chemical content of four cultivars of chokeberry fruits (Aronia melanocarpa). Not. Bot. Horti Agrobot. Cluj Napoca, 40(1), 253-260. https://doi.org/10.15835/nbha4017181

Peschel, W., Sanchez-Rabaneda, F., Diekmann, W., Plescher, A., Gartzia, I., Jimenez, D., ..., Codina, C. (2006). An industrial approach in the search of natural antioxidants from vegetable and fruit waste. Food Chem., 97(1), 137150. https://doi.org/10.1016/j.foodchem.2005.03.033

Sanchez-Moreno, C., Larrauri, J.A., Saura-Calixto, F. (1998). A procedure to measure the antiradical efficiency of polyphenols. J. Sci. Food Agric., 76(2), 270-276. https:// doi.org/10.1002/(SICI)1097-0010(199802)76:2<270:: AID-JSFA945>3.0.CO;2-9

Simić, V. M., Rajković, K. M., Stojičević, S. S., Veličković, D. T., Nikolić, N. Č., Lazić, M. L., Karabegović, I. T.
(2016). Optimization of microwave-assisted extraction of total polyphenolic compounds from chokeberries by response surface methodology and artificial neural network. Sep. Purif. Technol., 160, 89-97. https://doi. org/10.1016/j.seppur.2016.01.019

Simić, V. M., Stojičević, S. S., Veličković, D. T., Nikolić, N. Č., Lazić, M. L., Karabegović, I. T. (2018). RSM approach for modeling and optimization of microwave-assisted extraction of chokeberry. Adv. Technol., 7, 11-19. https://doi.org/10.5937/savteh1801011S

Singleton, V. L., Rossi, J. A. (1965). Colorimetry of total phenolics with phosphomolybdic-phosphotungstic acid reagents. Am. J. Enol. Viticult., 16, 144-158.

Skąpska, S., Marszałek, K., Woźniak, Ł., Zawada, K., Wawer, I. (2017). Aronia dietary drinks fortified with selected herbal extracts preserved by thermal pasteurization and high pressure carbon dioxide. LWT - Food Sci. Technol., 85, 423-426. https://doi.org/10.1016/j.lwt.2016.11.001

Sun, N. N., Wu, T. Y., Chau, C. F. (2016). Natural dietary and herbal products in anti-obesity treatment. Molecules, 21(10), e1351. https://doi.org/10.3390/molecules 21101351

Taheri, R., Connolly, B. A., Brand, M. H., Bolling, B. W. (2013). Underutilized chokeberry (Aronia melanocarpa, Aronia arbutifolia, Aronia prunifolia) accessions are rich sources of anthocyanins, flavonoids, hydroxycinnamic acids, and proanthocyanidins. J. Agric. Food Chem., 61(36), 8581-8588. https://doi.org/10.1021/ jf402449q

Thi, N. D., Hwang, E. S. (2014). Bioactive compound contents and antioxidant activity in Aronia (Aronia melanocarpa) leaves collected at different growth stages. Prev. Nutr. Food Sci., 19(3), 204-212. https://doi.org/10.3746/ pnf.2014.19.3.204

Tomšik, A., Pavlić, B., Vladić, J., Ramić, M., Brindza, J., Vidović, S. (2016). Optimization of ultrasound-assisted extraction of bioactive compounds from wild garlic ( $\mathrm{Al}$ lium ursinum L.). Ultrason. Sonochem., 29, 502-511. https://doi.org/10.1016/j.ultsonch.2015.11.005

Varzakas, T., Zakynthinos, G., Verpoort, F. (2016). Plant food residues as a source of nutraceuticals and functional foods. Foods, 5(4), e88. https://doi.org/10.3390/ foods5040088

Xu, Y. Y., Qiu, Y., Ren, H., Ju, D. H., Jia, H. L. (2017). Optimization of ultrasound-assisted aqueous two-phase system extraction of polyphenolic compounds from Aronia melanocarpa pomace by response surface methodology. Prep. Biochem. Biotechnol., 47(3), 312-321. https://doi. org/10.1080/10826068.2016.1244684 